\title{
Effect of Interaction Phenolic Compounds with Milk Proteins on Cell Line
}

\author{
Nayra Shaker Mehanna1, Zakaria Mohamed Rezk Hassan², Hala Mohamed Faker El-Din1, \\ Ali Abd-Elaziz Ali2, Ryszard Amarowicz ${ }^{3}$, Tamer Mohammed El-Messery ${ }^{{ }^{*}}$ \\ ${ }^{1}$ Dairy Science \&Technology Department, National Research Center, Dokki, Egypt \\ ${ }^{2}$ Food Science Department; Faculty of Agriculture, Ain Shams University, Cairo, Egypt \\ ${ }^{3}$ Institute of Animal Reproduction and Food Research of Polish Academy of Sciences, Division of Food Science, \\ Olsztyn, Poland \\ Email: ${ }^{\text {tmelmessery@yahoo.com }}$
}

Received 14 September 2014; revised 15 October 2014; accepted 2 November 2014

Copyright (C) 2014 by authors and Scientific Research Publishing Inc.

This work is licensed under the Creative Commons Attribution International License (CC BY).

http://creativecommons.org/licenses/by/4.0/

(c) (i) Open Access

\section{Abstract}

Plant flavonoids are polyphenolic compounds, commonly found in vegetables, fruits and many food sources that form a significant portion of our diet. These compounds act as anticancer and anti-proliferative but after interaction with milk proteins they form complexes which become less effective than these compounds alone. Investigation has been conducted to delineate the action of some phenolic compounds of natural origin and complexes formed from interactions between phenolic compounds and milk proteins in three human tumors cell lines: Breast (MCF7), Liver (HePG2) and colon (HCT116), these interactions were studied by fourier transform infrared spectroscopy (FTIR). Phenolic compounds have positive effect on human cancer cell lines but after interaction with milk protein and forming complexes, they become less effective than phenolics and some time have negative effect and become pro-cancer; this interaction can be studied by (FTIR) to know which groups do this complex. The spectra were recorded under conditions generally applied in quantitative work. IR spectra were recorded in the region from $4000-250 \mathrm{~cm}^{-1}$, but the bands in the region $4000-1400 \mathrm{~cm}^{-1}$ were analyzed in detail, since they are characteristic of $\mathrm{OH}$ groups while NH groups appeared at $\left(3000-4000 \mathrm{~cm}^{-1}\right)$ of various protonic species that undergo hydrogen bonding interaction. Another region of interest was the region from $1800-1400 \mathrm{~cm}^{-1}$, characteristic of the bending vibrations of the same group. Since the bands in this region were wide and complex.

\section{Keywords}

Phenolic Compounds, Protein, Interaction and Human Cell Line

\footnotetext{
${ }^{*}$ Corresponding author.
}

How to cite this paper: Mehanna, N.Sh., Hassan, Z.M.R., El-Din, H.M.F., Ali, A.A.-E., Amarowicz, R. and El-Messery, T.M. (2014) Effect of Interaction Phenolic Compounds with Milk Proteins on Cell Line. Food and Nutrition Sciences, 5, $2130-2146$. http://dx.doi.org/10.4236/fns.2014.522226 


\section{Introduction}

Phenolic compounds with anti-inflammatory and antioxidant activities play an important role in antitumor activity. Oxidative stress may cause damage to DNA, thus inducing mutations that may contribute to progressive tumor growth [1]. Several reports have demonstrated the anti-proliferative effects of herbal polyphenols, such as quercetin, in various human cancer cell lines [2] [3].

Phytochemicals are defined as bioactive nonessential nutrients from plants (phyto is derived from the Greek word phyto, which means plant). They have a variety of human health effects such as possessing putative chemoreventive properties (anticarcinogenic and antimutagenic) and interfering with tumor promotion and progression [4].

Natural phenolic compounds play an important role in cancer prevention and treatment. Phenolic compounds from medicinal herbs and dietary plants include phenolic acids, flavonoids, tannins, stilbenes, curcuminoids, coumarins, lignans, quinones, and others. Various bioactivities of phenolic compounds are responsible for their chemopreventive properties (e.g., antioxidant, anticarcinogenic, or antimutagenic and anti-inflammatory effects) and also contribute to their inducing apoptosis by arresting cell cycle, regulating carcinogen metabolism and ontogenesis expression, inhibiting DNA binding and cell adhesion, migration, proliferation or differentiation, and blocking signaling pathways. This review covers the most recent literature to summarize structural categories and molecular anticancer mechanisms of phenolic compounds from medicinal herbs and dietary plants [5].

Fourier Transform Infrared Spectroscopy FTIR is a technique that measures the infrared intensity versus wavenumber of light, by shining infrared radiation on sample protein, polypeptide backbone absorbs light and cause the vibration spectral band at different frequencies depended on wavelengths of radiation in the infrared region of the spectrum [6]. FTIR spectroscopy gives the information of protein conformation in the secondary structure. It is the technique capable of quantitative and qualitative analysis of chemical characteristics on the surfaces [7].

The objective of the study was to further our understanding of the interaction between some phenolics (Rosmarinic acid, Chlorogenic acid, Quercetin, Vanillin, Gallic acid, Caffic acid, Catechin and some Tannins), and milk proteins (casein and whey proteins isolate), because this interaction reduces the nutritional value of the milk proteins and phenolic compounds as anticancer so the aim of this study is to know effect these interactions of phenolic compounds as anticancer on human cells line.

\section{Materials and Methods}

\subsection{Materials}

Fresh cow's skim milk was obtained from faculty of agriculture, Cairo University. Whey proteins isolate (WPI) was obtained from Davisco Foods International Inc. (Minnesota, USA). Sodium di basic from Egyptian Co., Sodium mono basic from MERCK (Darmstadt-Germany), Ethanol from sd. fine-Chem. Limited, Catechin was purchased from Fluka Chemical Co., Gallic and Rosemarinic acids were obtained from MP Biomedical LLC. Caffic acid was purchased from Bio Basic INC. Vanillin and Chlorogenic acid, from Roth GmbH Co. Qurecetin, from ALDRICH. Sephadex LH-20 and tannic acid from Sigma, Chinese green tea leaves, walnut, lentil from Poland-Olsztyn,

\subsection{Methods}

\subsubsection{Preparation of Casein Powder}

Casein powder was prepared from fresh cow’s skim milk according to Morr [8].

\subsubsection{Preparation of Standard Phenolic Compounds Solution}

Phenolic compounds (Catechin, Gallic acid, Qurecetin, Caffic acid and Vanillin) were dissolved separately in $0.1 \mathrm{M}$ sodium phosphate buffer $\mathrm{pH} 7(0.1 \% \mathrm{w} / \mathrm{v})$ while Chlorogenic acid and Rosemarinic acid were dissolved separately in ethanol $(0.1 \% \mathrm{w} / \mathrm{v})$.

Extraction of tannins: Extraction of tannins from walnut, green tea and lentil were attained according Kosińska [9].

Cell culture: Cytotoxic effect on human cell line (HePG2: Human hepatocellular carcinoma cell line), (MCF7: Human Caucasian breast adenocarcinoma) and (HCT116: Colon cell line): Cell viability was assessed 
by the mitochondrial dependent reduction of yellow MTT (3-(4,5-dimethylthiazol-2-yl)-2,5-diphenyl tetrazolium bromide) to purple formazan [10]. All procedures were done in a sterile area using a Laminar flow cabinet biosafety class II level (Baker, SG403INT, Sanford, ME, USA). Cells were suspended in RPMI 1640 medium for HePG2-MCF7 and HCT116-DMEM for A549. The absorbance was then measured using a microplate multiwell reader (Bio-Rad Laboratories Inc., model 3350, Hercules, California, USA) at $595 \mathrm{~nm}$ and a reference wavelength of $620 \mathrm{~nm}$. A statistical significance was tested between samples and negative control (cells with vehicle) using independent t-test by SPSS 11 program.

\subsubsection{Preparation Sample for Fourier Transform Infrared Spectroscopy (FTIR)}

$10 \mathrm{mg}$ Milk proteins (10\% W/V) samples were dissolved in $50 \mu \mathrm{l} 0.1 \mathrm{M}$ Sodium phosphate buffer at $\mathrm{pH} 7$ and mixed with Phenolic compounds ( $1 \mathrm{mg} / 1 \mu \mathrm{l}$ buffer) solutions to give a final protein concentration of $10 \%$ containing $1 \%$ Phenolic compounds. The solution was initially freeze dried, SUBLIMATOR, VaCo5, ZIRBUS technology, Germany. FTIR (JASCO FT/IR 6100 using KBr Wafer technique Kim and Kim [11] was performed on Milk proteins and Phenolic compounds.

\section{Results and Discussion}

Casein and WPI are contributes to beneficial therapeutic effects, including anti-cancer; casein and WPI directly targets both tumor cells and tumor vasculature, thereby inhibiting tumor growth, proliferation, and angiogenesis of HePG2 and MCF7 but without any effect on HCT116, Table 1.

\subsection{FTIR Spectra}

The spectra were recorded under conditions generally applied in quantitative work. IR spectra were recorded in the region from $4000-250 \mathrm{~cm}^{-1}$, but the bands in the region $4000-1400 \mathrm{~cm}^{-1}$ were analyzed in detail, since they are characteristic of $\mathrm{OH}$ groups while $\mathrm{NH}$ groups were appeared at $\left(3000-4000 \mathrm{~cm}^{-1}\right)$ of various protonic species that undergo hydrogen bonding interaction. Another region of interest was the region from 1800 - 1400 $\mathrm{cm}^{-1}$, characteristic of the bending vibrations of the same group. Since the bands in this region are wide and complex.

Interaction of casein and whey protein with phenolic compounds was determined by FTIR; it was found that some complexes exhibit hydrogen bonding. Also, electrostatic interaction plays a dominant role in the stabilization of the peptide by phenolic compounds. Phenolic molecules have been placed appropriately near the side chain groups of the peptide. The functional groups para- $\mathrm{OH}(\rho-\mathrm{OH})$ meta- $\mathrm{OH}(\mathrm{m}-\mathrm{OH})$ and $\mathrm{COOH}$ of Phenolics have been assumed to act as a hydrogen bond donor/acceptor for different side chain groups of amino acid [12].

The FTIR spectrum of pure casein and whey protein surface displays two characteristic bands at (1648 - 1649) $\mathrm{cm}^{-1}$ respectively, (amide-I) band arises predominantly from the protein amide $\mathrm{C}=\mathrm{O}$ stretching vibrations, and $\left(1536\right.$ - 1547) $\mathrm{cm}^{-1}$, respectively, (amide-II) band is due to the amide N-H bending vibrations and C-N stretching vibrations as mentioned by Huang [5].

Fourier transform infrared spectroscopy (FTIR) spectrum of pure WPI displays two characteristic bands of amide $\mathrm{I}\left(1649 \mathrm{~cm}^{-1}\right)$ which associated with $\mathrm{C}=\mathrm{O}$ stretching vibration, and amide $\Pi\left(1547 \mathrm{~cm}^{-1}\right)$ which resultant from N-H bending vibration. But the FTIR spectrum of casein revealed that amid I and $\Pi$ were at 1648 and 1563 $\mathrm{cm}^{-1}$ respectively. The significant peak position shifts absorbed in amide I and $\Pi$ bands attributed to hydrogen bonding between all phenolics and milk whey proteins. The interactions between WPI and some mono-, di- and polyphenolic compounds were illustrated in Figures 1(a)-(j). on the other hand the interactions between casein and some mono-, di- and polyphenolic compounds were illustrated in Figures 1(k)-(t).

\subsection{Interactions with Mono-Phenolic Compounds}

Chloroginic acid has anticancer effect on all tumor cells but this effect more significance on (HePG2). This result agree with Takahama [13] where showed that chlorogenic acid could also inhibit the formation of DNA single strand breaks and prevent the formation of dinitrogen trioxide by scavenging nitrogen dioxide generated in the human oral cavity.

On the other hand complex chloroginic-WPI appears against effect on (MCF7), but this complex has significant effect on (HePG2); while the complex chloroginic-casein appeared against effect on (HCT116). The interaction 
Table 1. Cytotoxic activity of phenolic compounds against the human tumor cell line.

\begin{tabular}{|c|c|c|c|}
\hline Sample & MCF $7 \%$ at $100 \mathrm{ppm}$ & HePG $2 \%$ at $100 \mathrm{ppm}$ & HCT $116 \%$ at $100 \mathrm{ppm}$ \\
\hline Casein-chlorogenic acid & 38.5 & 49.5 & 0.0 \\
\hline WPI-chlorogenic acid & 0.0 & 65.7 & 1.5 \\
\hline Chlorogenic acid & 40.6 & 95.1 & 9.2 \\
\hline Casein-caffeic acid & 15.5 & -114 & 0.0 \\
\hline WPI-caffeic acid & 21.5 & 45.8 & 0.0 \\
\hline Caffeic acid & 47.8 & 67.1 & 0.0 \\
\hline Casein-gallic aicd & 11.3 & 48.4 & 0.0 \\
\hline WPI-gallic acid & 8.7 & 45.8 & 0.0 \\
\hline Gallic acid & 84.4 & 100 & 76.8 \\
\hline Casein-vanillin & 9.5 & 83.8 & 5.1 \\
\hline WPI-vanillin & 24.4 & 26.3 & 10.2 \\
\hline Vanillin & 71.4 & 95.1 & 28.3 \\
\hline Casein-rosemarinic acid & 3.8 & 46.9 & 0.0 \\
\hline WPI-rosemarinic acid & 23.8 & 23.5 & 0.0 \\
\hline Rosemarinic acid & 51.1 & 67.1 & 32.1 \\
\hline Casein-catechin & 0.0 & 51.1 & 3.1 \\
\hline WPI-catechin & 25.4 & 72.1 & 1.4 \\
\hline Catechin & 30.4 & 72.2 & 58.7 \\
\hline Casein-qurecetin & 29 & -58 & 0.0 \\
\hline WPI-qurecetin & 27.6 & 80.3 & 0.0 \\
\hline Qurecetin & 50.5 & 82.2 & 7.0 \\
\hline Casein- tannic acid & 11.4 & 71.5 & 0.0 \\
\hline WPI-tannic acid & 15.2 & 78.7 & 0.0 \\
\hline Tannic acid & 28.4 & 96.4 & 13.8 \\
\hline Casein-tannins (walnut) & 28.2 & 80 & 11.5 \\
\hline WPI-tannins (walnut) & 6.4 & 35.5 & 2.6 \\
\hline Tannins (walnut) & 52.6 & 90.2 & 15 \\
\hline Casein-tannins (green tea) & 6.2 & 73.5 & 1.4 \\
\hline WPI-tannins (green tea) & 17.6 & 72.5 & 15.5 \\
\hline Tannins (green tea) & 45.3 & 100 & 33.2 \\
\hline Casein & 40.1 & 36.8 & 0.0 \\
\hline WPI & 21.1 & 78.7 & 0.0 \\
\hline Buffer & 32.2 & 0.0 & 5.3 \\
\hline DMSO & 3.0 & 1.0 & 1.0 \\
\hline Negative control & 0.0 & 0.0 & 0.0 \\
\hline
\end{tabular}

Sample concentration ranged between (100 to $0.78 \mathrm{ppm}$ ) using MTT assay. HEPG2: (Human hepatocellular liver carcinoma cell line). HCT116: (Colon cell line). MCF7: (Human Caucasian breast adenocarcinoma). 


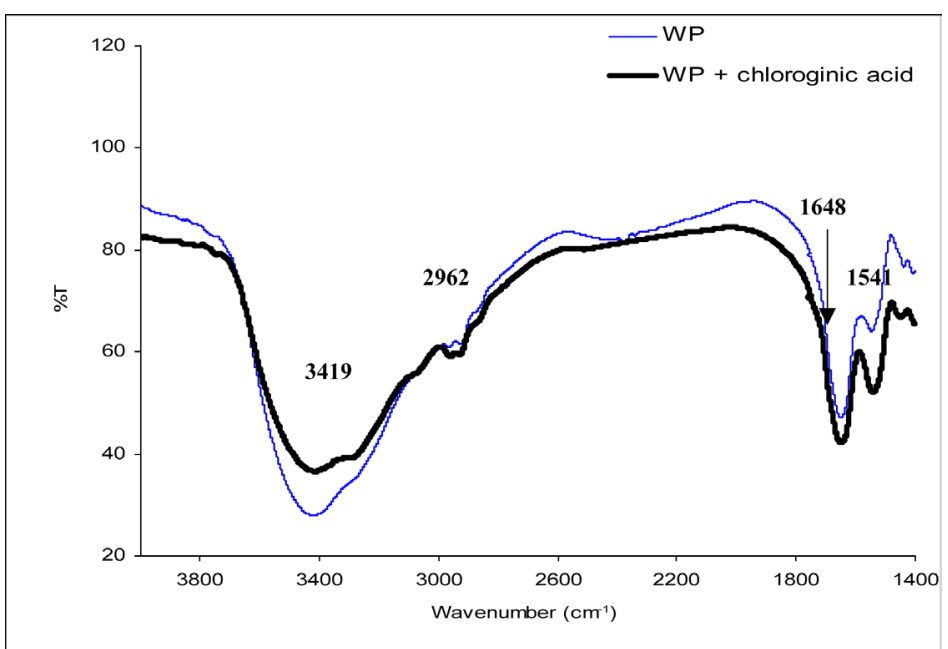

(a)

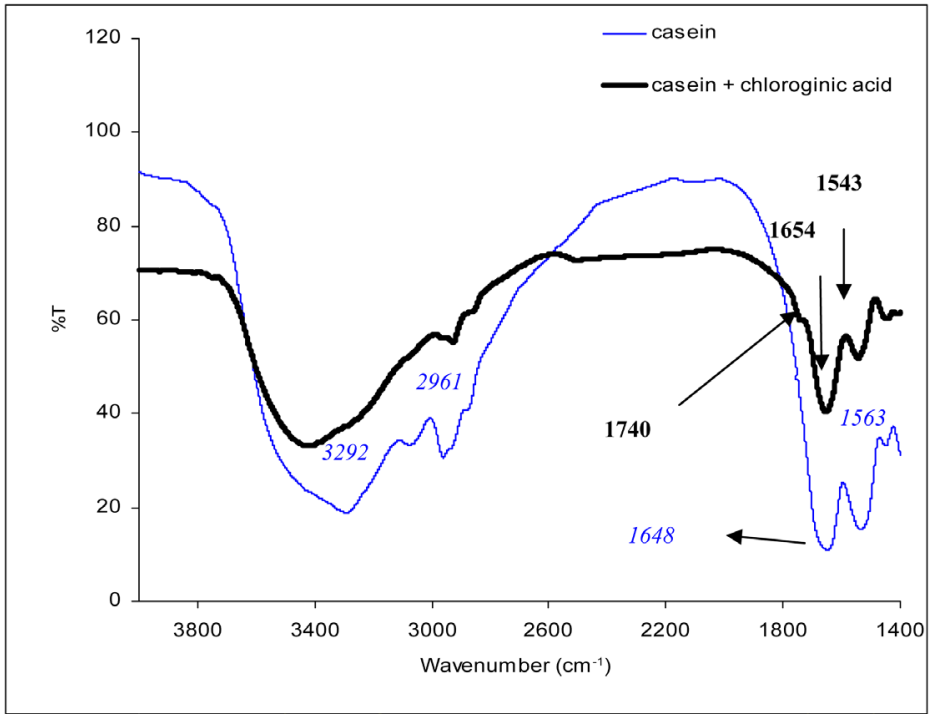

(b)

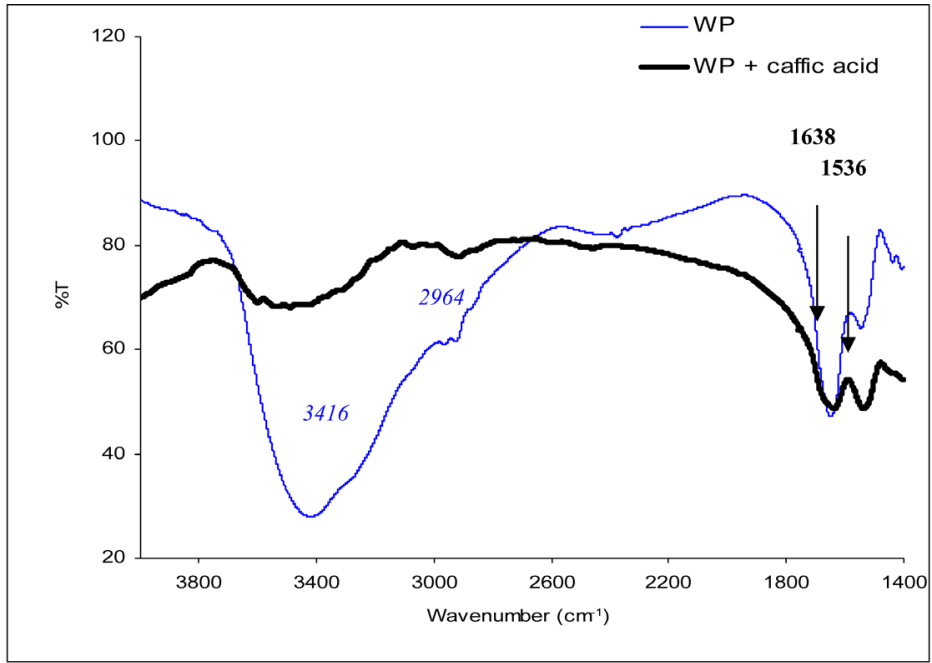

(c) 


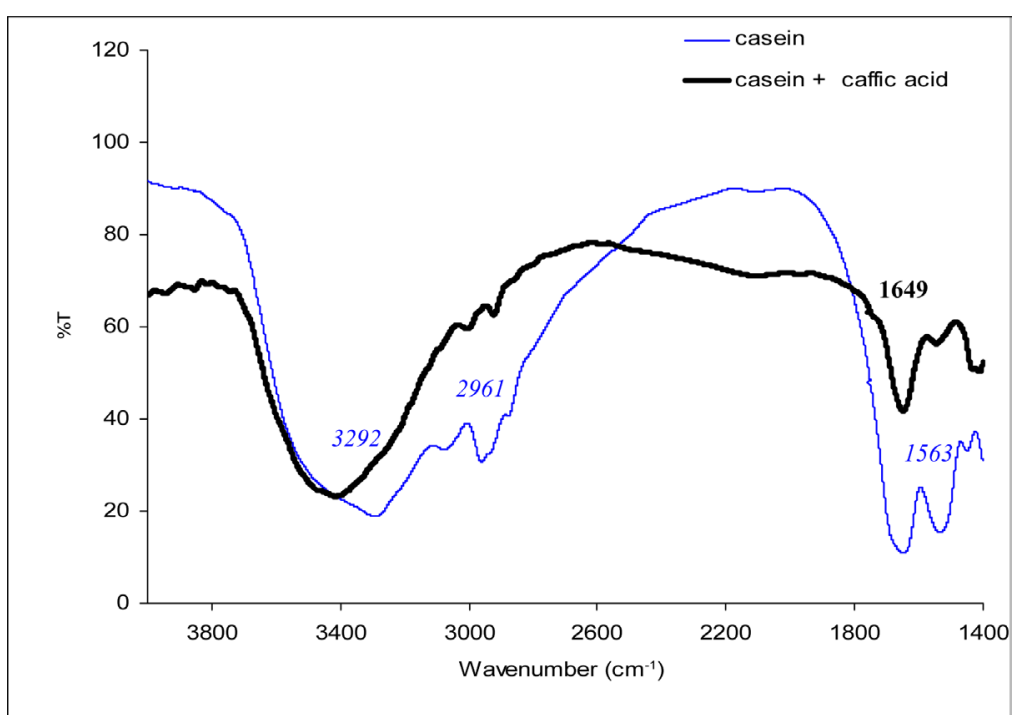

(d)

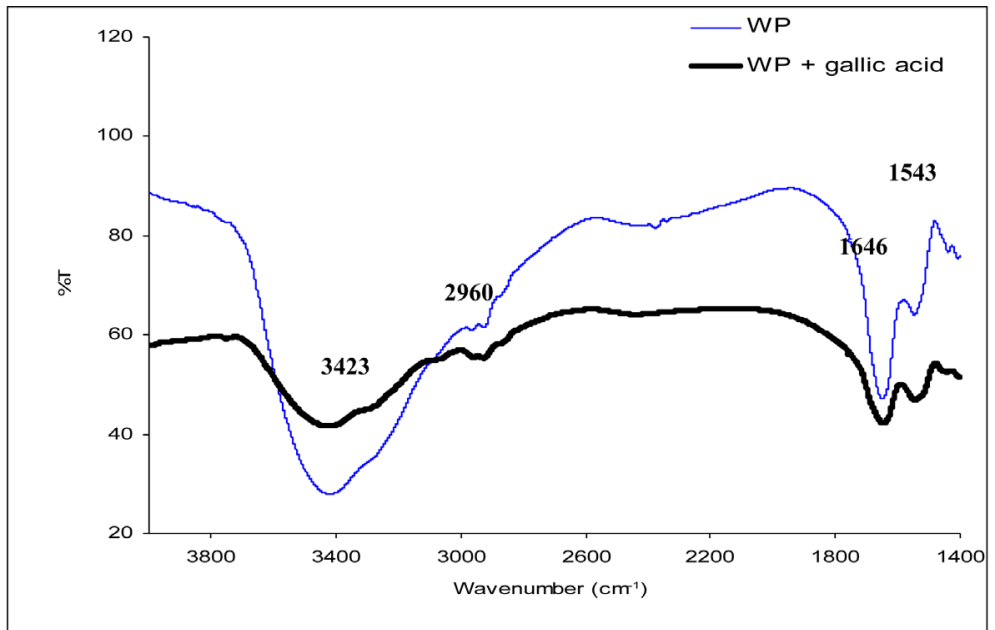

(e)

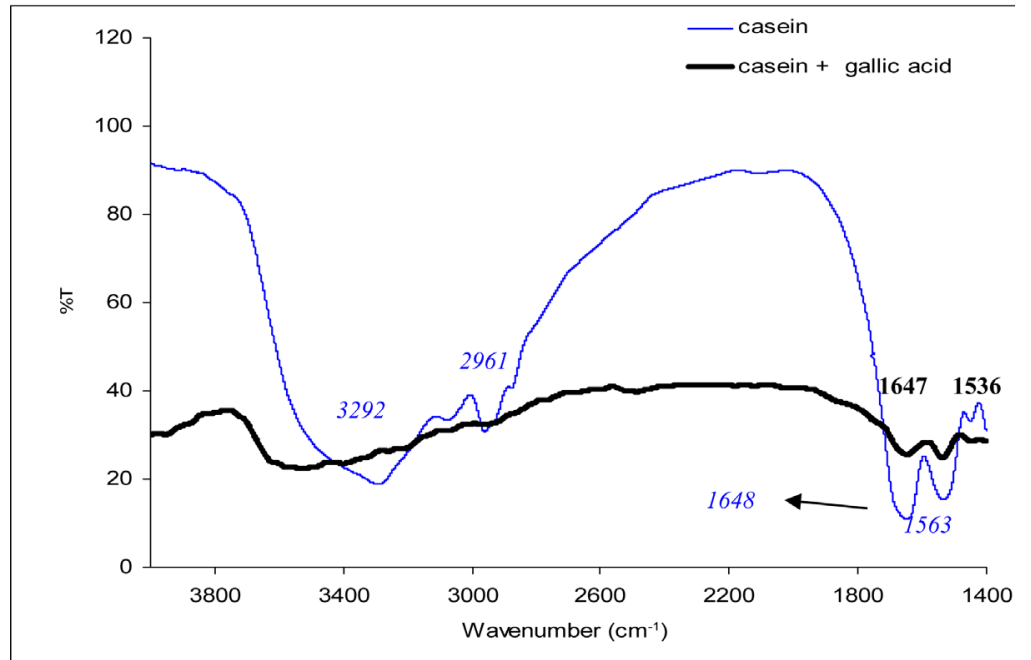

(f) 


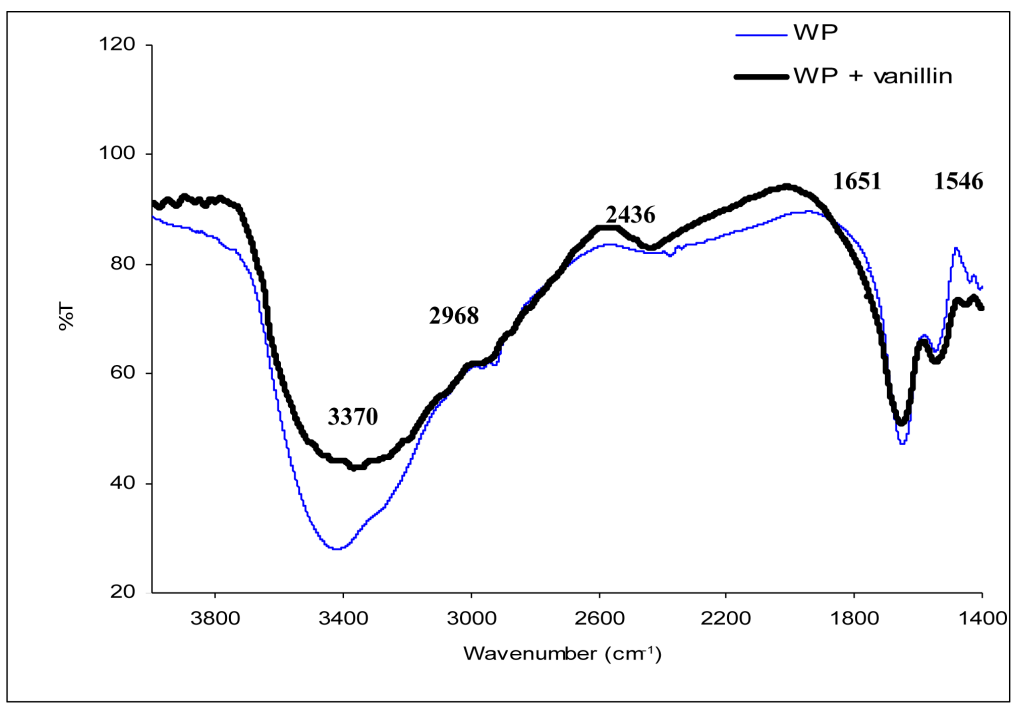

(g)

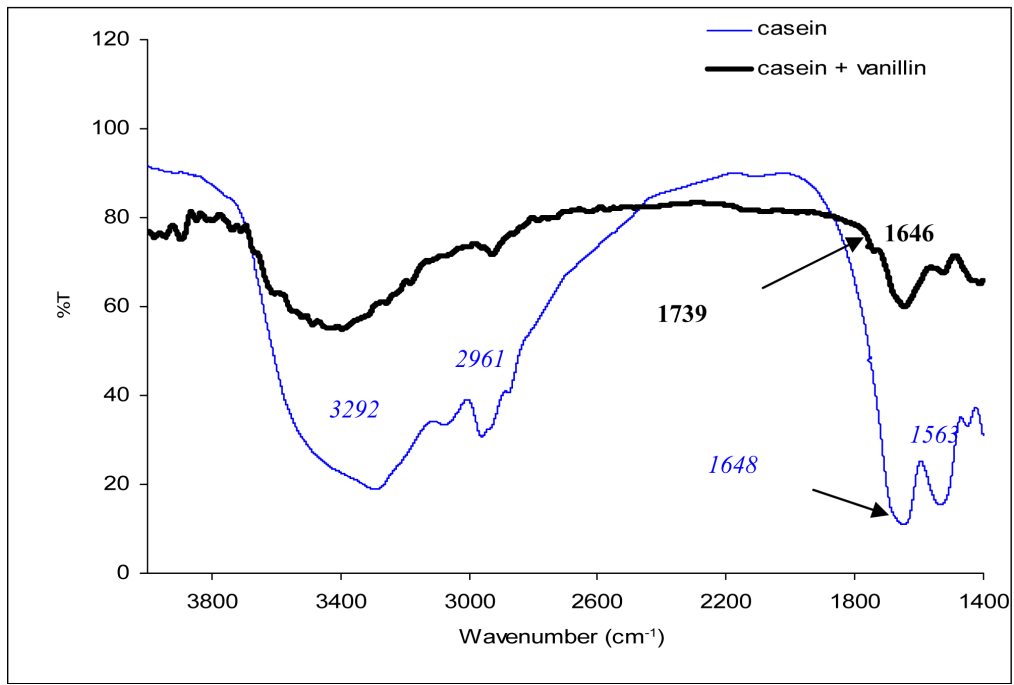

(h)

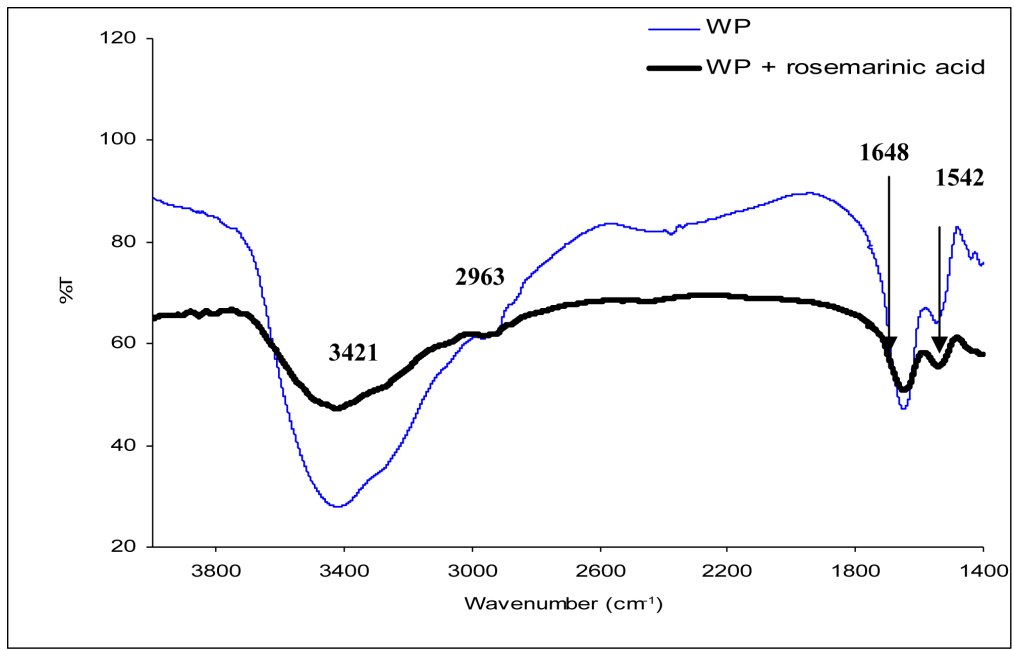

(i) 


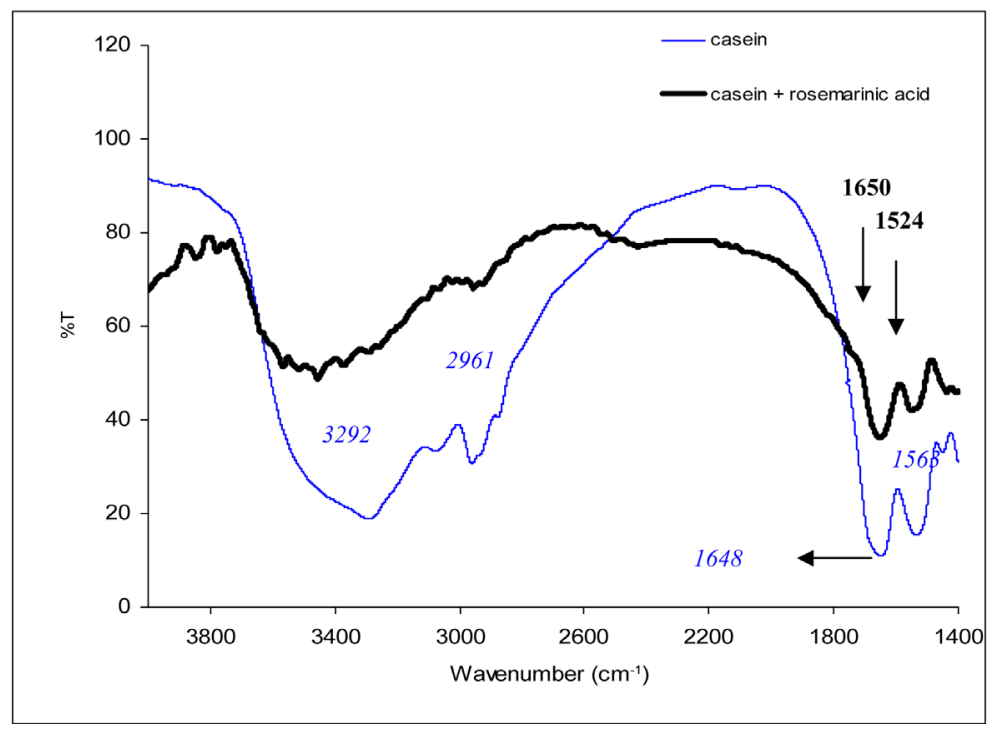

(j)

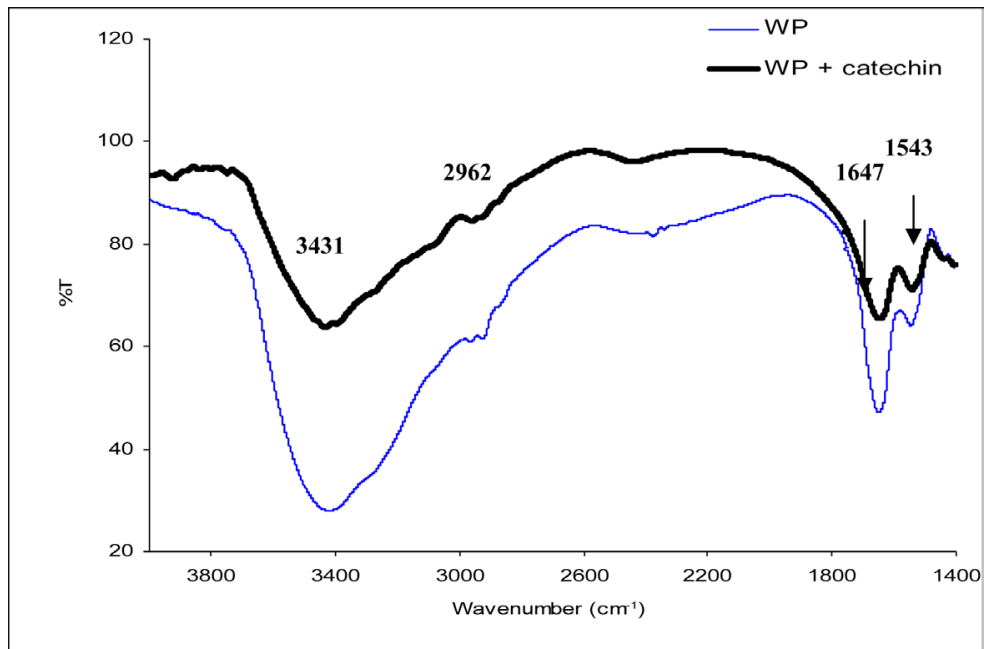

(k)

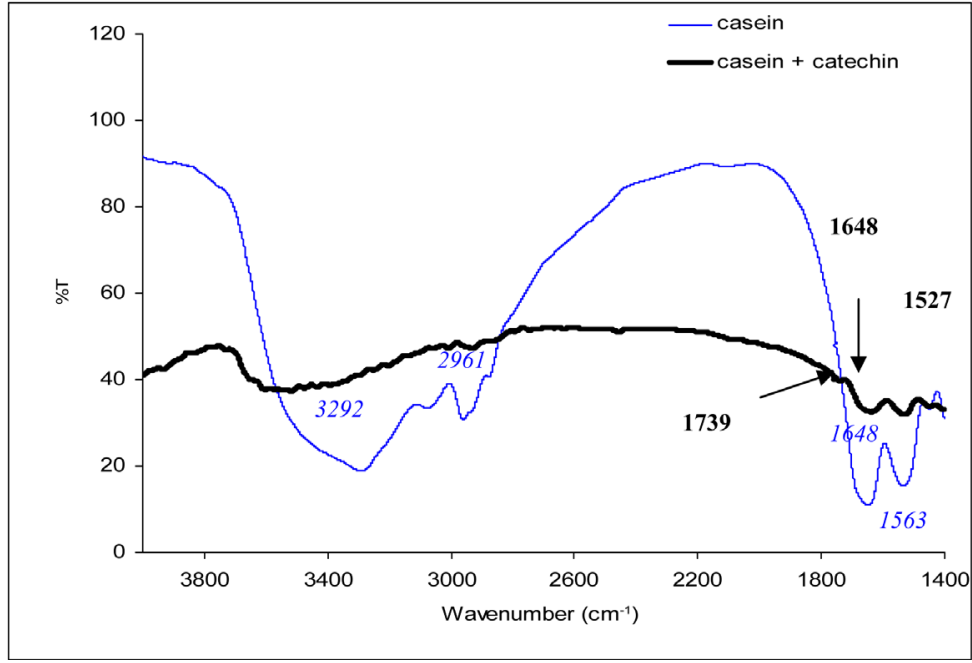

(l) 


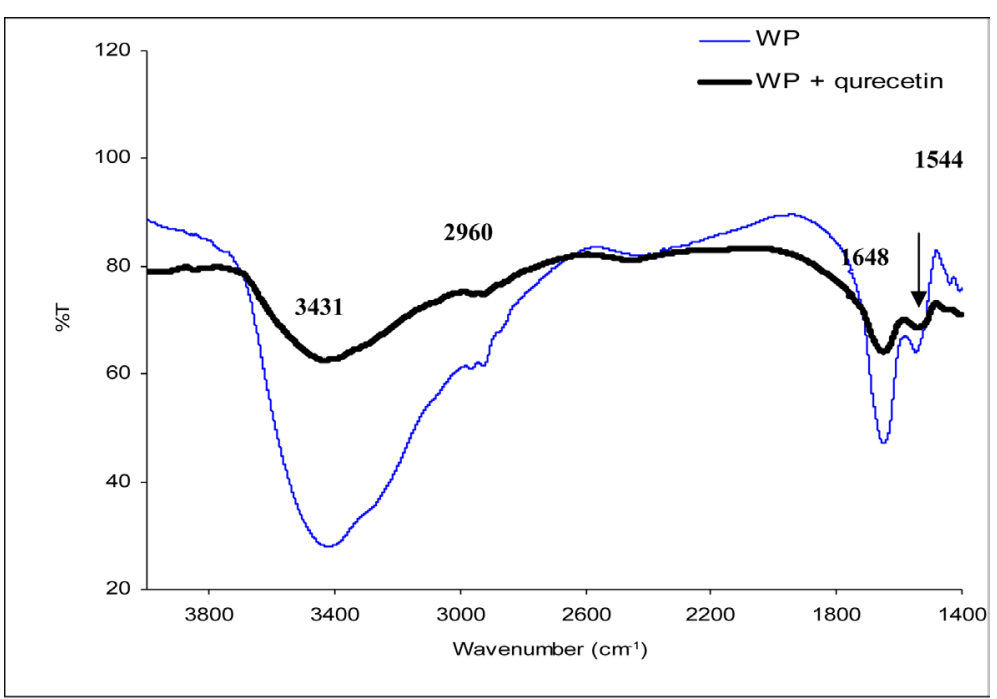

(m)

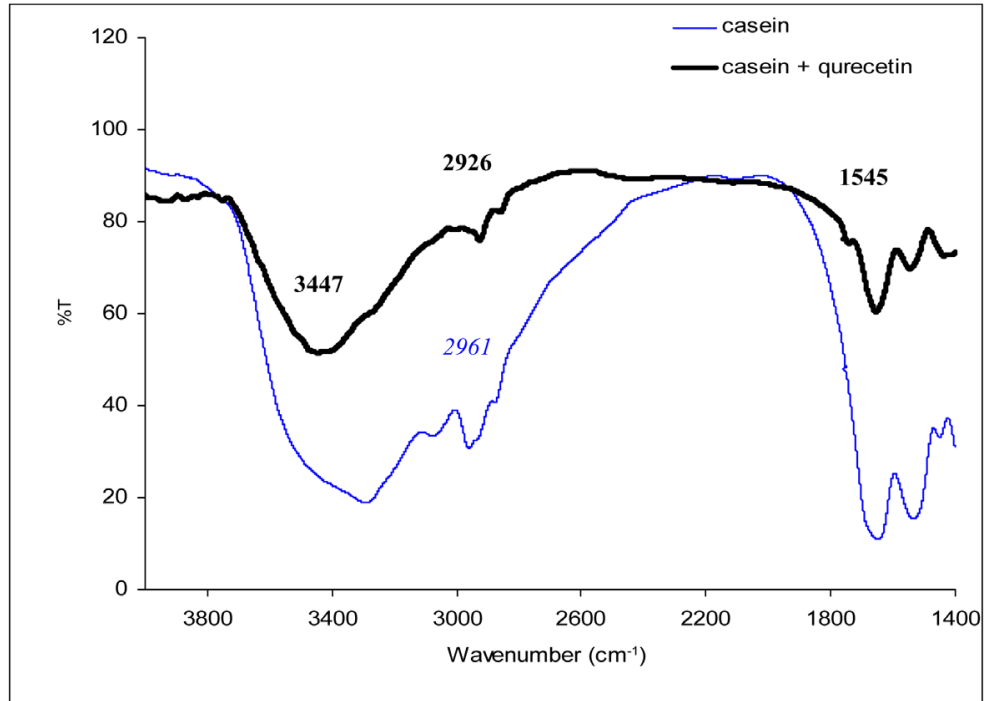

(n)

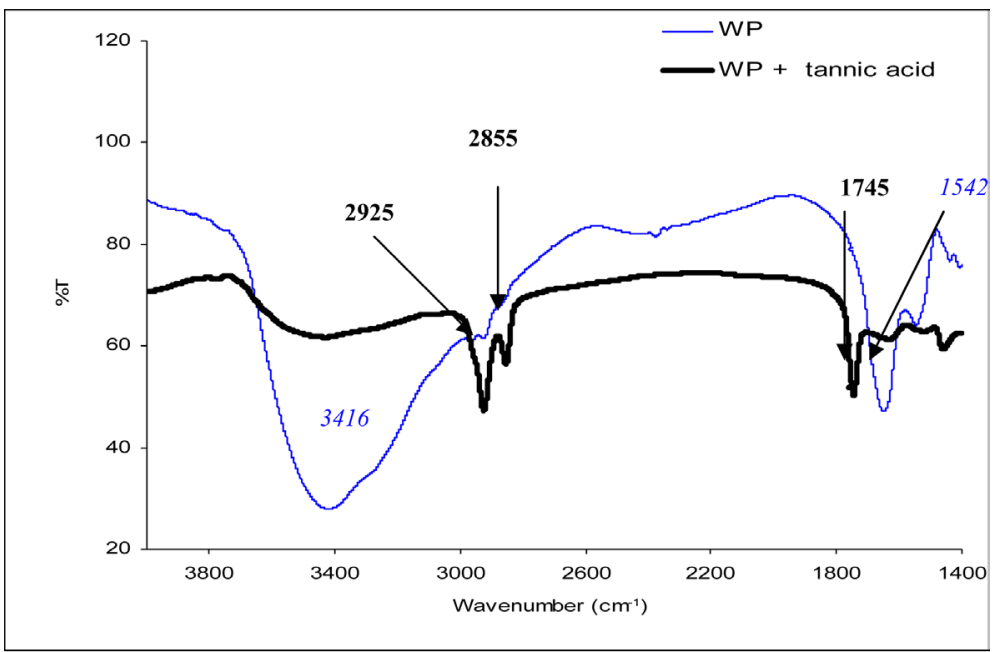

(o) 


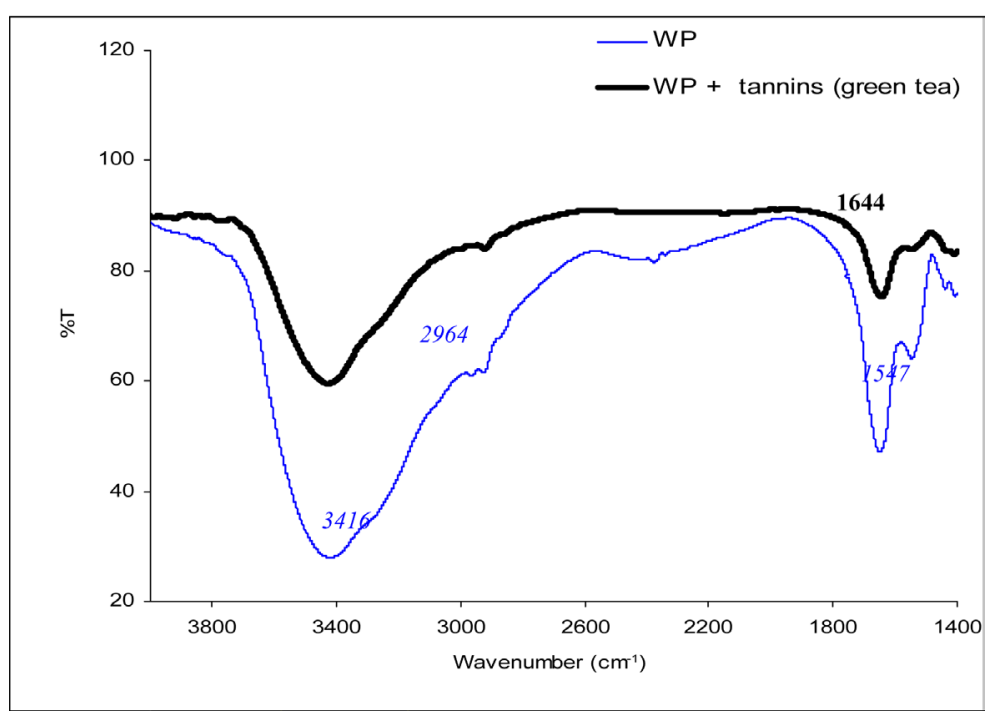

(p)

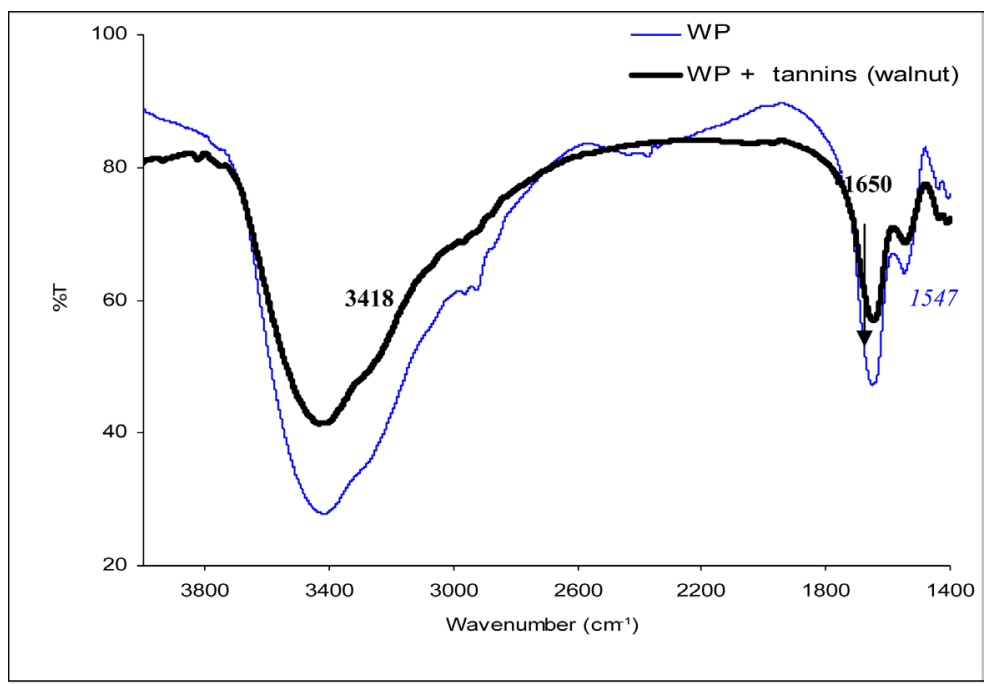

(q)

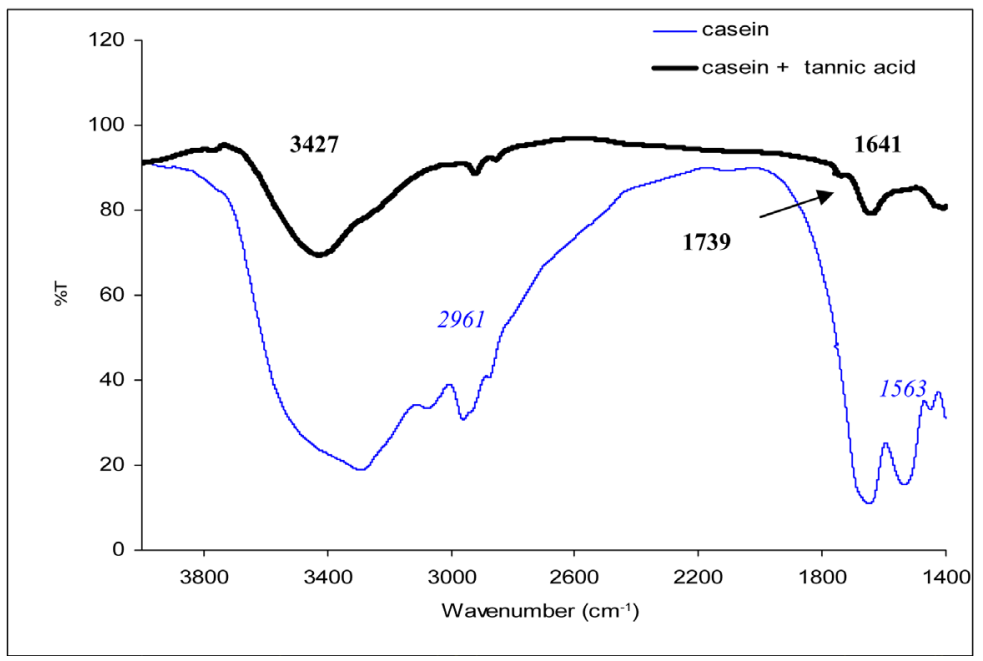

(r) 


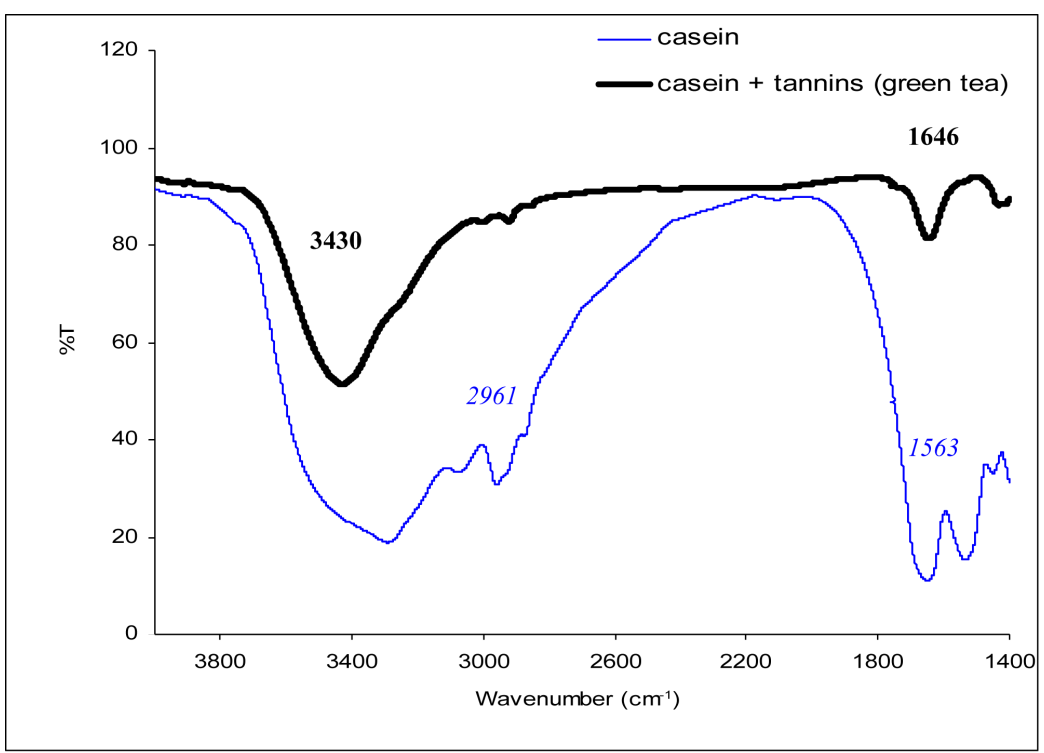

(s)

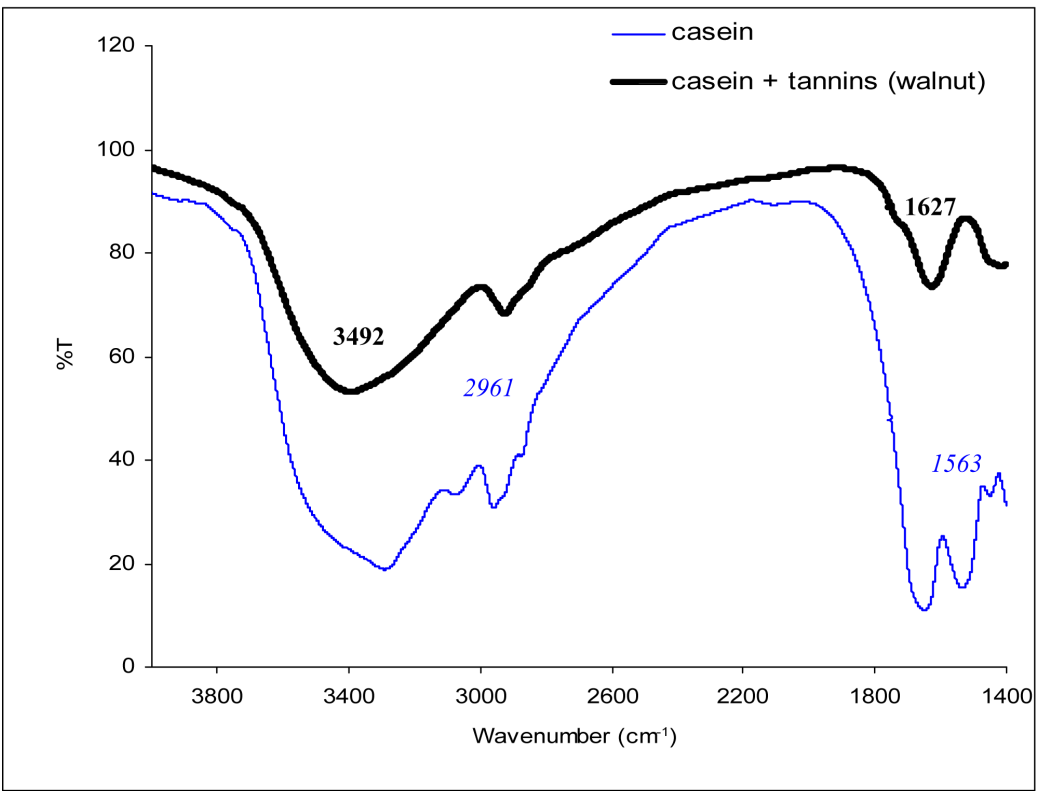

(t)

Figure 1. Function group for complex milk protein with phenolic compounds.

chloroginic acid with milk proteins lost effect on all cells, Table 1; this may be due to interaction between chloroginic acid and WPI was weak. The results in Figure 1(a) elucidated that amid I and $\Pi$ of chloroginic-WPI acid complex appeared at 1648, $1541 \mathrm{~cm}^{-1}$ respectively and $\mathrm{NH}_{2}$ group in complex appeared near control, Figure 1(b) showed that amid I and $\Pi$ for casein-chloroginic acid complex appeared at 1654 and $1543 \mathrm{~cm}^{-1}$ respectively, also ester group at $1740 \mathrm{~cm}^{-1}$ was formed, while $\mathrm{NH}_{2}$ group in complex was near control (casein only).

Caffeic acid has positive effect on HePG2 and MCF7 but without effect on HCT116, Table 1; this agree with Surh [4]. Han [14] showed that caffeic acids, (an analog of phenolic acids) modulate the ceramide-induced signal transduction pathway, suppress the activation of nuclear factor kappa-lightchain-enhancer of activated cells, and inhibit protein tyrosine kinase activity. caffeic acids could also inhibit tumor promotion, epidermal growth factor and tumor necrosis factor-alpha production [4]. Moreover, some phenolic acids (caffeic acid, ferulic acid, gallic acid, protocatechuic acid, etc.) in grape extracts and wine contribute to their activity against various types 
of cancer such as breast, lung, and gastric cancer [15].

While complex caffeic-WPI and caffeic-casein were appeared negative affect on (HCT116), but positive effect on (MCF7), while caffeic-casein has negative effect on (HEPG2), but caffeic-WPI has positive effect on (HEPG2). The interaction caffeic acid with milk proteins has lost effect on all tumor cells. Table 1 these due to the strong interaction between them in Figure 1(c); the function groups of WPI-caffic acid complex as comparison with WPI, amid I and $\Pi$ appeared at $1638 \mathrm{~cm}^{-1}$ respectively and $\mathrm{NH}_{2}$ group was disappeared, this means that interaction between caffic acid and WPI was strong and this agree with the pervious results Hassan [16]. Amid I for the casein-caffic acid complex appeared at $1649 \mathrm{~cm}^{-1}$ while amid $\Pi$ disappeared, but $\mathrm{NH}_{2}$ group was near control (Figure 1(d)).

The inhibitory effect of caffeic acid was greater than that of chlorogenic acid with treatments at the same concentration; Caffeic acid is one of the major metabolites produced by the hydrolyzation of chlorogenic acid, Because a large amount of chlorogenic acid is absorbed in the metabolized form, considerable attention has been focused on the biological effects of metabolites such as caffeic acid in order to evaluate possible in vivo effects of chlorogenic acid-containing diets [17].

Table 1 elucidated that gallic acid has significant inhibitory effect on all tumor cell proliferation. Gallic acid as a natural antioxidant had significant inhibitory effects on cell proliferation, induced apoptosis in a series of cancer cell lines, and showed selective cytotoxicity against tumor cells with higher sensitivity than normal cells [18].

While complex gallic-WPI and gallic-casein were appeared negative effect on (HCT116), but positive effect on (HePG2) and (MCF7) The interaction gallic acid with milk proteins has lost effect on all cells, Table 1; these interaction appeared in Figure 1(e) showed that amid I and $\Pi$ for WPI-gallic acid complex appeared at 1646 and $1544 \mathrm{~cm}^{-1}$ respectively and $\mathrm{NH}_{2}$ group disappeared. In Figure 1(f), amid I and $\Pi$ for a complex of casein-gallic acid appeared at $1647-1536 \mathrm{~cm}^{-1}$ respectively, $\mathrm{NH}_{2}$ group disappeared, this indicated that interaction between casein and gallic acid was strong. The present findings indicate that these peptidases are strongly inhibited by low concentrations of gallic acid, which is a common constituent of edible foods Thus; the intake of such compounds as dietary constituents may interfere with the absorption of amino acids from intestine [19]. The present data support the contention that gallic acid, a constituent of dietary polyphenols may interfere in the digestion and absorption of proteins in rat intestine.

Table 1 showed that vanillin had significant inhibitory effects on cell proliferation MCF7 and HePG. Vanillin, a food flavoring agent, has been reported to show anti-cancer activity and to inhibit chemical carcinogenesis; vanillin has anti-cancer potential by decreasing invasiveness of cancer cells. Since vanillin is generally regarded as safe, it may be of value in the development of anti-cancer drugs for cancer treatment [20].

The complex vanillin-casein has significant effect on HePG2, and positive effect MCF7 and HCT116 the same effect for vanillin-WPI on all tumor cells; Table 1. Also showed the effect vanillin on tumor cells was higher sensitivity than complex. These interactions were appeared in Figure 1 (g). Amid I and $\Pi$ resulting from the interaction between WPI and vanillin appeared at $1651-1546 \mathrm{~cm}^{-1}$ respectively and $\mathrm{NH}_{2}$ group appeared near control (WPI), this indicated that the interaction between WPI and Vanillin was weak, Figure 1(h) showed interaction between casein and vanillin, amid I and ester group for the complex appeared at $1646-1739 \mathrm{~cm}^{-1}$ respectively, amid $\Pi$ and $\mathrm{NH}_{2}$ group disappeared. The hydrogen bonding/ionic interaction or hydrophobic interaction was envisaged in the interaction of chloroginic acid with proteins [21].

\subsection{Interactions with Di-Phenolic Compound}

Rosmarinic acid is an antioxidant phenolic compound, which is found in many dietary spices such as mint, sweet basil, oregano, rosemary, sage, and thyme [22]. So rosmarinic acids was appeared positive effect on all tumor cells and significant effect of HePG2.

The complex rosmarinic acid-casein has negative effect on HCT116, and positive effect on MCF7 and HePG2 while rosmarinic acid-WPI without effect on HCT116 and positive effect on MCF7 and HePG2. The interaction rosmarinic acid has lost effect on all cells, Table 1. Figure 1(i) showed the function group for WPI-rosmarinic acid complex amid I and $\Pi$ appeared $1648-1542 \mathrm{~cm}^{-1}$ respectively and $\mathrm{NH}_{2}$ group decreased in complex. Amid I and $\Pi$ of the casein-rosemarinic acid complex appeared at 1650 and $1524 \mathrm{~cm}^{-1}$ respectively (Figure 1(j)), while $\mathrm{NH}_{2}$ group disappeared in complex. The changes in tryptophan microenvironment polarity are probably related to chemical structure of each rosmarinic acid, namely to the number and position of hydroxyl groups. 
Hydrophobicity around tryptophan residues rose with increasing number of hydroxyl groups in the molecule of rosmarinic acid. However, the position of hydroxyl groups on the benzene ring seemed to be also important, [23].

Catechins from green tea belong to the family of flavonoids that are powerful antioxidants and free iron scavengers. Many botanical flavonoids possess strong antioxidant activities in the cardiovascular system [24]. Effects of catechins on cancer chemoprevention have been attributed to its antioxidant activities [25] [26].

Table 1 showed that catechins as well as their inhibition of the proliferation of human tumor cell lines, this effect was significant with HePG2, the results agree with Gu [27], them show that catechin is contributes to beneficial therapeutic effects, including anti-oxidant, antiinflammatory, anti-cancer, and immunomodulatory effects; catechin directly targets both tumor cells and tumor vasculature, thereby inhibiting tumor growth, proliferation, migration, and angiogenesis of breast cancer.

Where catechin content prompted the evaluation of their in vitro inhibitory effects on cyclooxygenase enzymes and on the proliferation of human cancer cell lines; the cyclooxygenase inhibitory activities of anthocyanidins and catechins as well as their inhibition of the proliferation of human tumor cell lines suggest that these compounds can be further investigated for their health benefits. The use of these bioflavonoids as potential phytoceuticals could be significant in the prevention of fatal diseases such as cancer and crippling inflammatory conditions such as arthritis and gout [28].

The complex catechin-casein has effect on HCT116 and HePG2, but negative effect on MCF7, while catechin-WPI has effect on MCF7and HCT116 but significant effect on HePG2, interaction between catechin and milk protein lost effect on all cells was lower effect that catechin as free phenolic compound. Table 1; Figure 1(k) showed that amid I and $\Pi$ for WPI-catechin complex was appeared at 1644 and $1543 \mathrm{~cm}^{-1}$ respectively and $\mathrm{NH}_{2}$ group decreased, this means that there was interaction between catechin and WPI. Moreover, amid I and $\Pi$ for casein-catechin complex appeared at $1648-1527 \mathrm{~cm}^{-1}$ respectively, ester group was formed at $1739 \mathrm{~cm}^{-1}$ $\mathrm{NH}_{2}$ group disappeared, this means that the interaction between casein and catechin was very strong (Figure 1(I)).

Quercetin is one of the most potent antioxidants, anti-inflammatory, antiproliferative, and has effect on all tumor cells but significant effect on (HePG2) Table 1, quercetin acts as an anticancer agent through modulation of cell cycle, protein, oncogenes, and antioncogenes [29]. Quercetin is a flavonoid present in many vegetables, fruits and beverages.

The complex quercetin-casein has negative effect on HePG2 and HCT116, but positive effect on MCF7, while quercetin-WPI has effect on MCF7 and without effect on HCT116 but has significant effect on HePG2. Interaction between quercetin and milk proteins was the lowest effect from quercetin as control, Table 1. On the other hand amid I and $\Pi$ for WPI-qurecetin complex (Figure 1(m)) appeared at 1648 and $1544 \mathrm{~cm}^{-1}$ respectively and $\mathrm{NH}_{2}$ group was greatly decreased, consequently the interaction was strong. In Figure 1(n) functional groups for complex of casein-qurecetin, amid I and $\Pi$ at $1653-1545 \mathrm{~cm}^{-1}$ respectively, also ester group appeared at $1741 \mathrm{~cm}^{-1}$ and $\mathrm{NH}_{2}$ group decreased, this means that interaction between qurecetin and casein was strong. The interaction between molecules including hydrogen bonding, ionic and van der Waals interactions; Protein-qurecetin interactions play an important role in a variety of biological processes [30].

\subsection{Interaction with Poly-Phenolic Compound}

Table 1 elucidated that tannic acid and fractions tannins as antiproliferative has positive effect of all tumor cells, but this effect was significant on HePG2. Tannins are a large class of polyphenolics in dietary plants and medicinal herbs. Oligomeric proanthocyanidins, which are widely distributed in grape seed and skin and pine bark, are considered to be the most potent antioxidants and frequently used in health care and cancer treatment. It is also known that many plants containing tannins are effective against cancer and tumors [31]. Tannins are natural, water-soluble, polyphenolic compounds with molecular weight ranging from 500 to 4000, usually classified into 2 classes: hydrolysable tannins (gallo- and ellagi-tannins) and condensed tannins (proanthocyanidins) [32].

Hydrolysable tannins and condensed tannins are powerful antioxidant agents because they havemany hydroxyl groups, especially many ortho-dihydroxyl or galloyl groups. Bigger tannin molecules possess more galloy and ortho-dihydroxyl groups, and their activities are stronger [33]. In addition, these tannins also exhibit strong antibacterial, antiulcer, anti-inflammatory, antileishmanial, antimutagenic, enzyme regulating, signal transduction pathways blocking, and apoptotic activities; thus, they have attracted wide attention for cancer treatment [34]- 
[37].

The Table 1 showed that complex tannic acid-casein and tannic acid-WPI were positive effect on MCF7 and significant effect on HePG2; but this complex have negative effect on HCT116. The complex tannins (walnut and green tea)-casein and WPI were positive effect of all tumor cells, but tannins (green tea)-WPI was significant effect on HePG2. On the other hand complex tannins (lentil)-casein and WPI have effect on MCF7 and HCT116 but negative effect on HePG2. However interaction between tannins and milk protein lost effect on cell line and this may be due to the strong interaction between them and it's appeared in Figures 1(o)-(q) illustrated interaction between WPI and plyphenolics (tannins), amid I for WPI-tannic acid complex appeared at $1631 \mathrm{~cm}^{-1}$, ester group for complex appeared at $1745 \mathrm{~cm}^{-1}$ while $\mathrm{NH}_{2}$ group was disappeared, this means that the interactions between WPI and tannic acid was strong as comparably with the tannins from green tea and walnut in Figure 1(p) and Figure 1(q) respectively. On the other hand the interaction between WPI and tannins in green tea was stronger than tannins in walnut. Figures 1(r)-(t) illustrated the interaction between casein and polyphenolics (tannins). Amid I for casein-tanninc acid complex appeared at $1641 \mathrm{~cm}^{-1}$, also ester group appeared at $1739 \mathrm{~cm}^{-1}$ while amid $\Pi$ disappeared, this indicated that the interaction between casein and tannic acid was very strong as comparably with the tannins from green tea and walnut, hence, ester group did not form. As shown in Figure 1(s) and Figure 1(t) amid I appeared at $1646-1627 \mathrm{~cm}^{-1}$ respectively, while amid $\Pi$ disappeared for all tannins. Tannins, in general have been reported to bind to a variety of proteins by interacting with free $\mathrm{NH}_{2}$ or SH groups [19].

The amide I, II, and III are the most noticeable, easily measured, and are sensitive to conformational of backbone that links the amino acids. Amide I band represent stretching vibration of the $\mathrm{C}=\mathrm{O}$ bond while amide II band provides primarily to bending vibrations of the N-H bond. Amide I band share with in-plane $\mathrm{NH}$ bending and C-N stretching, so the frequency of this vibration depends on the hydrogen bonding between the $\mathrm{C}=\mathrm{O}$ and $\mathrm{NH}$ which varies for the different secondary structure of polypeptides. Since amide III band is relatively weak and is affected by other vibration, most studies have focused on amide I and II band [38] [39].

The positions of amide bands I and II in phenolics transmission with milk protein surface show a remarkable shift from $1636 \mathrm{~cm}^{-1}$ to $1649 \mathrm{~cm}^{-1}$ and from 1536 to $1547 \mathrm{~cm}^{-1}$ respectively. The significant peak position shifts observed in the amide I and amide II bands may be attributed to hydrogen bonding between all phenolics and milk protein, suggesting that the hydrogen bonding may occur between the phenolic carboxyl groups in phenolic compounds and the functional groups (i.e. amide groups) of the milk protein [7]. The positions of ester in phenolics (vanillin, tannic acid, catechin, qurecetin and choloroginic acid) transmission with milk protein surface show a remarkable shift from $1739 \mathrm{~cm}^{-1}$ to $1741 \mathrm{~cm}^{-1}$. Its form hydrogen bonding may occur between the phenolic hydroxyl groups in phenolic compounds and the functional groups (i.e. carboxyl groups) of the milk protein.

It can be distinguished from nitro and cyano by their IR spectra. Amides exhibit a moderately intense V band near $1650 \mathrm{~cm}^{-1}$.

Amide linkages constitute a defining molecular feature of proteins, the secondary structure of which is due in part to hydrogen bonding abilities of amides.

Because of the greater electronegativity of oxygen, the carbonyl $(\mathrm{C}=\mathrm{O})$ is a stronger dipole than the N-C dipole. The presence of a $\mathrm{C}=\mathrm{O}$ dipole and, to a lesser extent a $\mathrm{N}-\mathrm{C}$ dipole, allows amides to act as H-bond acceptors. In primary and secondary amides, the presence of $\mathrm{N}-\mathrm{H}$ dipoles allows amides to function as H-bond donors as well. Thus amides can participate in hydrogen bonding with water and other protic solvents; the oxygen atom can accept hydrogen bonds from water and the $\mathrm{N}-\mathrm{H}$ hydrogen atoms can donate $\mathrm{H}$-bonds. As a result of interactions such as these, the water solubility of amides is greater than that of corresponding hydrocarbons.

\section{Conclusions}

The aim of the present study was to investigate the binding type between phenolics compounds and casein or whey protein isolate, using different approaches. It may be assumed that the initial binding between phenolics and milk proteins yields soluble complexes which upon subsequent cross-linking are transformed into insoluble precipitates.

Cross-linking of milk proteins is an important fact because of potential effects on textural properties of milk products, e.g., yogurt and cheese. The cross-linking effect of vanillin phenolic on milk proteins can be used for manufacturing of milk products (ice cream) with desired textural properties. 
Phenolic compunds act as anticancer and anti-proliferative but after interaction with milk proteins, they form complexes which become less effective than these compounds alone.

Fourier transform infrared spectroscopy (FTIR) spectrum of pure WPI displays two characteristic bands of amide I $\left(1649 \mathrm{~cm}^{-1}\right)$ which associated with $\mathrm{C}=\mathrm{O}$ stretching vibration, and amide $\Pi\left(1547 \mathrm{~cm}^{-1}\right)$ which resultant from $\mathrm{N}-\mathrm{H}$ bending vibration. But the FTIR spectrum of casein revealed that amid I and $\Pi$ were at 1648 and 1563 $\mathrm{cm}^{-1}$ respectively. The significant peak position shifts absorbed in amide I and $\Pi$ bands attributed to hydrogen bonding between all phenolics and milk proteins.

Therefore, interactions of vanillin phenolic with milk proteins must be considered in this regard. Nevertheless, they may be acceptable food additives because of their antioxidant and anticarcinogenic activities; so they also contribute to the functionality of the products. Displaying the interactions of phenolic compounds with milk proteins is a necessary subject, as they may be potential food additives.

\section{Acknowledgements}

The authors express their gratitude to Dr. Wael S. I. Abou-Elmagd Associate Professor of Organic Chemistry, Chemistry Department, Faculty of Science, Ain Shams University, Cairo, Egypt.

\section{References}

[1] Gerhäuser, C., Klimo, K., Heiss, E., Neumann, I., Eldeen, A.G., Knauft, J., Liu, G.Y., Sitthimonchai, S. and Frank, N. (2003) Mechanism-Based in Vitro Screening of Potential Cancer Chemopreventive Agents. Mutation Research, 523, 163-172. http://dx.doi.org/10.1016/S0027-5107(02)00332-9

[2] Haghiac, M. and Walle, T. (2005) Quercetin Induces Necrosis and Apoptosis in SCC-9 Oral Cancer Cells. Nutrition and Cancer, 53, 220-231. http://dx.doi.org/10.1207/s15327914nc5302 11

[3] Bishayee, K., Ghosh, S., Mukherjee, A., Sadhukhan, R., Mondal, J. and Khuda-Bukhsh, A.R. (2013) Quercetin Induces Cytochrome-c Release and ROS Accumulation to Promote Apoptosis and Arrest the Cell Cycle in G2/M, in Cervical Carcinoma: Signal Cascade and Drug-DNA Interaction. Cell Proliferation, 46, 153-163. http://dx.doi.org/10.1111/cpr.12017

[4] Surh, Y.J. (2003) Cancer Chemoprevention with Dietary Phytochemicals. Nature Reviews Cancer, 3, 768-780. http://dx.doi.org/10.1038/nrc1189

[5] Huang, Q., Wang, X. and Ho, C.T. (2007) Investigation of Adsorption Behavior of (-)-Epigallocatechin Gallate on Bovine Serum Albumin Surface Using Quartz Crystal Microbalance with Dissipation Monitoring. Journal of Agricultural and Food Chemistry, 55, 10110-10116. http://dx.doi.org/10.1021/jf072236t

[6] Creighton, T.E. (2002) Proteins: Structures and Molecular Properties. 2nd Edition, W.H. Freeman and Company, New York, 190 p.

[7] Chitpan, M. (2009) Monitoring the Binding Processes of Black Tea Polyphenols to Bovine Serum Albumin Surface Using Quartz Crystal Microbalance with Dissipation Monitoring. PhD. Thesis, The State University of New Jersey, New Jersey.

[8] Morr, C.V. (1985) Functionality of Heated Milk Protein in Dairy and Related Foods. Journal of Dairy Science, 68, 2773-2781. http://dx.doi.org/10.3168/jds.S0022-0302(85)81165-6

[9] Kosińska, A., Karamać, M., Penkacik, K., Urbalewicz, A. and Amarowicz, R. (2011) Interactions between Tannins and Proteins Isolated from Broad Bean Seeds (Vicia faba Major) Yield Soluble and Non-Soluble Complexes. European Food Research and Technology, 233, 213-222. http://dx.doi.org/10.1007/s00217-011-1506-9

[10] Mosmann, T. (1983) Rapid Colorimetric Assays for Cellular Growth and Survival: Application to Proliferation and Cytotoxicity Assays. Journal of Immunological Methods, 65, 55-63. http://dx.doi.org/10.1016/0022-1759(83)90303-4

[11] Kim, J.T. and Kim, M.C. (1986) Silicon Wafer Technique for Infrared Spectra of Silica and Solid Samples (I). Korean Journal of Chemical Engineering, 3, 45-51. http://dx.doi.org/10.1007/BF02697522

[12] Madhan, B., Thanikaivelan, P., Subramanian, V., Raghava, R.J., Balachandran, U.N. and Ramasami, T. (2001) Molecular Mechanics and Dynamics Studies on the Interaction of Gallic Acid with Collagen-Like Peptides. Chemical Physics Letters, 346, 334-340. http://dx.doi.org/10.1016/S0009-2614(01)00910-1

[13] Takahama, U., Ryu, K. and Hirota, S. (2007) Chlorogenic Acid in Coffee Can Prevent the Formation of Dinitrogen Trioxide by Scavenging Nitrogen Dioxide Generated in the Human Oral Cavity. Journal of Agricultural and Food Chemistry, 55, 9251-9258. http://dx.doi.org/10.1021/jf071700r

[14] Han, X.Z., Shen, T. and Lou, H.X. (2007) Dietary Polyphenols and Their Biological Significance. International Journal of Molecular Sciences, 8, 950-988. http://dx.doi.org/10.3390/i8090950 
[15] Stagos, D., Kazantzoglou, G., Theofanidou, D., Kakalopoulou, G. and Magiatis, P. (2006) Activity of Grape Extracts from Greek Varieties of Vitis vinifera against Mutagenicity Induced by Bleomycin and Hydrogen Peroxide in Salmonella typhimurium Strain TA102. Mutation Research: Genetic Toxicology and Environmental Mutagenesis, 609, 165175. http://dx.doi.org/10.1016/j.mrgentox.2006.06.032

[16] Hassan, Z.M.R., El Din, H.M.F., Ali, A.A., Mehanna, N.S.H. and El-Messery, T.M. (2013) Interaction of Some Low Molecular Weight Phenolics with Milk Proteins. World Applied Sciences Journal, 23, 182-187.

[17] Kang, N.J., Lee, K.W., Shin, B.J., Jung, S.K., Hwang, M.K., Bode1, A.M., Heo, Y., Lee, H.J. and Dong, Z. (2009) Caffeic Acid, a Phenolic Phytochemical in Coffee, Directly Inhibits Fyn Kinase Activity and UVB-Induced COX-2 Expression. Carcinogenesis, 30, 321-330. http://dx.doi.org/10.1093/carcin/bgn282

[18] Faried, A., Kurnia, D., Faried, L.S., Usman, N. and Miyazaki, T. (2007) Anticancer Effects of Gallic Acid Isolated from Indonesian Herbal Medicine, Phaleria macrocarpa (Scheff.) Boerl, on Human Cancer Cell Lines. International Journal of Oncology, 30, 605-613.

[19] Mahajan, N. and Mahmood, L. (2009) Effect of Gallic Acid on Alkaline Phosphatase and Peptidase Activities in Rat Intestine. Indian Journal of Biochemistry and Biophysics, 46, 378-382.

[20] Lirdprapamongkol, K., Sakurai, H., Kawasaki, N., Choo, M., Saitoh, Y., Aozuka, Y., Singhirunnusorn, P., Ruchirawat, S., Svasti, J. and Saiki, I. (2005) Vanillin Suppresses in Vitro Invasion and in Vivo Metastasis of Mouse Breast Cancer Cells. European Journal of Pharmaceutical Sciences, 25, 57-65. http://dx.doi.org/10.1016/j.ejps.2005.01.015

[21] Suryaprakash, P. and Prakash, V. (1995) Interaction of 3’-O-caffeoyl D-quinic Acid with Multisubunit Protein Helianthinin. Journal of Biosciences, 20, 531-549. http://dx.doi.org/10.1007/BF02703536

[22] Shan, B., Cai, Y.Z., Sun, M. and Corke, H. (2005) Antioxidant Capacity of 26 Spice Extracts and Characterization of Their Phenolic Constituents. Journal of Agricultural and Food Chemistry, 53, 7749-7759. http://dx.doi.org/10.1021/jf051513y

[23] Trnková, L., Bousova, I., Kubicek, V. and Drsata, J. (2010) Binding of Naturally Occurring Hydroxycinnamic Acids to Bovine Serum Albumin. Science and Research, 2, 563-570.

[24] Wang, C.Z., Mehendale, S.R., Calway, T. and Yuan, C.S. (2011) Botanical Flavonoids on Coronary Heart Disease. The American Journal of Chinese Medicine, 39, 661-671. http://dx.doi.org/10.1142/S0192415X1100910X

[25] Kumar, N., Shibata, D., Helm, J., Coppola, D. and Malafa, M. (2007) Green Tea Polyphenols in the Prevention of Colon Cancer. Frontiers in Bioscience, 12, 2309-2315. http://dx.doi.org/10.2741/2233

[26] Mak, J.C. (2012) Potential Role of Green Tea Catechins in Various Disease Therapies: Progress and Promise. Clinical and Experimental Pharmacology and Physiology, 39, 265-273. http://dx.doi.org/10.1111/j.1440-1681.2012.05673.X

[27] Gu, J.W., Makey, K.L., Tucker, K.B., Chinchar, E., Mao, X., Pei, I., Thomas, E.Y. and Miele, L. (2013) EGCG, a Major Green Tea Catechin Suppresses Breast Tumor Angiogenesis and Growth via Inhibiting the Activation of HIF-1 $\alpha$ and NF $\kappa$ B, and VEGF Expression. Vascular Cell, 5, 9. http://dx.doi.org/10.1186/2045-824X-5-9

[28] Seeram, N.P., Zhang, Y. and Nair, M.G. (2003) Inhibition of Proliferation of Human Cancer Cells and Cyclooxygenase Enzymes by Anthocyanidins and Catechins. Nutrition and Cancer, 46, 101-106. http://dx.doi.org/10.1207/S15327914NC4601_13

[29] Levy, J., Teuerstein, I., Marbach, M., Radian, S. and Sharoni, Y. (1984) Tyrosine Protein Kinase Activity in the DMBA-Induced Rat Mammary Tumor: Inhibition by Quercetin. Biochemical and Biophysical Research Communications, 123, 1227-1233. http://dx.doi.org/10.1016/S0006-291X(84)80264-8

[30] Fu, Z.D., Chen, X.Q. and Jiao, F.P. (2012) Study of Interaction of Galangin, Kaempferol and Qurecetin with BSA. Latin American Applied Research, 42, 211-216.

[31] Huh, Y.S., Hong, T.H. and Hong, W.H. (2004) Effective Extraction of Oligomeric Proanthocyanidin (OPC) from Wild Grape Seeds. Biotechnology and Bioprocess Engineering, 9, 471-475. http://dx.doi.org/10.1007/BF02933488

[32] Cai, Y.Z., Luo, Q., Sun, M. and Corke, H. (2004) Antioxidant Activity and Phenolic Compounds of 112 Traditional Chinese Medicinal Plants Associated with Anticancer. Life Sciences, 74, 2157-2184. http://dx.doi.org/10.1016/j.lfs.2003.09.047

[33] Cai, Y.Z., Sun, M., Xing, J., Luo, Q. and Corke, H. (2006) Structure-Radical Scavenging Activity Relationships of Phenolic Compounds from Traditional Chinese Medicinal Plants. Life Sciences, 78, 2872-2888. http://dx.doi.org/10.1016/j.lfs.2005.11.004

[34] Souza, S.M.C., Aquino, L.C.M., Milach, A.C., Bandeira, M.A.M. and Nobre, M.E.P. (2007) Antiinflammatory and Antiulcer Properties of Tannins from Myracrodruon urundeuva Allemao (Anacardiaceae) in Rodents. Phytotherapy Research, 21, 220-225. http://dx.doi.org/10.1002/ptr.2011

[35] Joanisse, G.D., Bradley, R.L., Preston, C.M. and Munson, A.D. (2007) Soil Enzyme Inhibition by Condensed Litter Tannins May Drive Ecosystem Structure and Processes: The Case of Kalmia angustifolia. New Phytologist, 175, 535546. http://dx.doi.org/10.1111/j.1469-8137.2007.02113.x 
[36] Larrosa, M., Tomas-Barberan, F.A. and Espin, J.C. (2006) The Dietary Hydrolysable Tannin Punicalagin Releases Ellagic Acid That Induces Apoptosis in Human Colon Adenocarcinoma Caco-2 Cells by Using the Mitochondrial Pathway. The Journal of Nutritional Biochemistry, 17, 611-625. http://dx.doi.org/10.1016/j.jnutbio.2005.09.004

[37] Nomura, M., Tsukada, H., Ichimatsu, D., Ito, H. and Yoshida, T. (2005) Inhibition of Epidermal Growth FactorInduced Cell Transformation by Tannins. Phytochemistry, 66, 2038-2046. http://dx.doi.org/10.1016/j.phytochem.2005.01.018

[38] Ng, C., Losso, J.N., Marshall, W.E. and Rao, R.M. (2002) Freundlich Adsorption Isotherms of Agricultural ByProduct-Based Powdered Activated Carbons in a Geosmin-Water System. Bioresources Technology, 85, 131-135. http://dx.doi.org/10.1016/S0960-8524(02)00093-7

[39] Ge, D., Shi, W., Ren, L., Zhang, F., Zhang, X. and Zhang, Q. (2006) Variation Analysis of Affinity-Membrane Model Based on Freundlich Adsorption. Journal of Chromatography, 1114, 40-44. http://dx.doi.org/10.1016/j.chroma.2006.02.026 
Scientific Research Publishing (SCIRP) is one of the largest Open Access journal publishers. It is currently publishing more than 200 open access, online, peer-reviewed journals covering a wide range of academic disciplines. SCIRP serves the worldwide academic communities and contributes to the progress and application of science with its publication.

Other selected journals from SCIRP are listed as below. Submit your manuscript to us via either submit@scirp.org or Online Submission Portal.
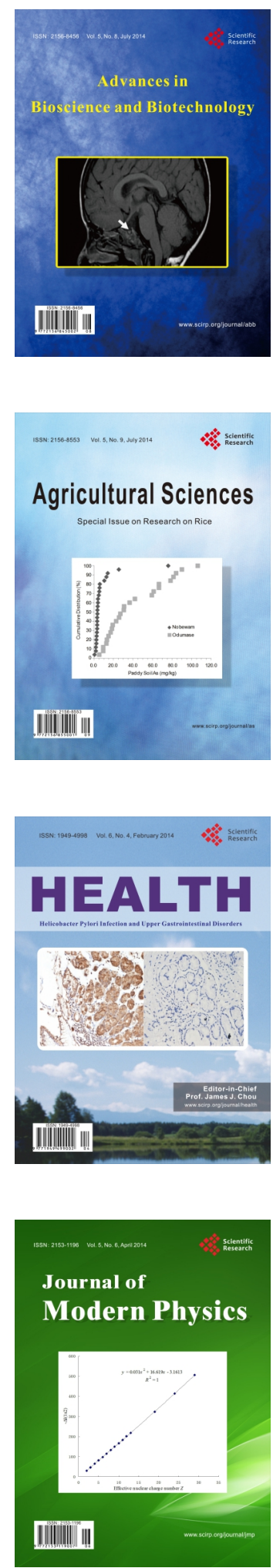
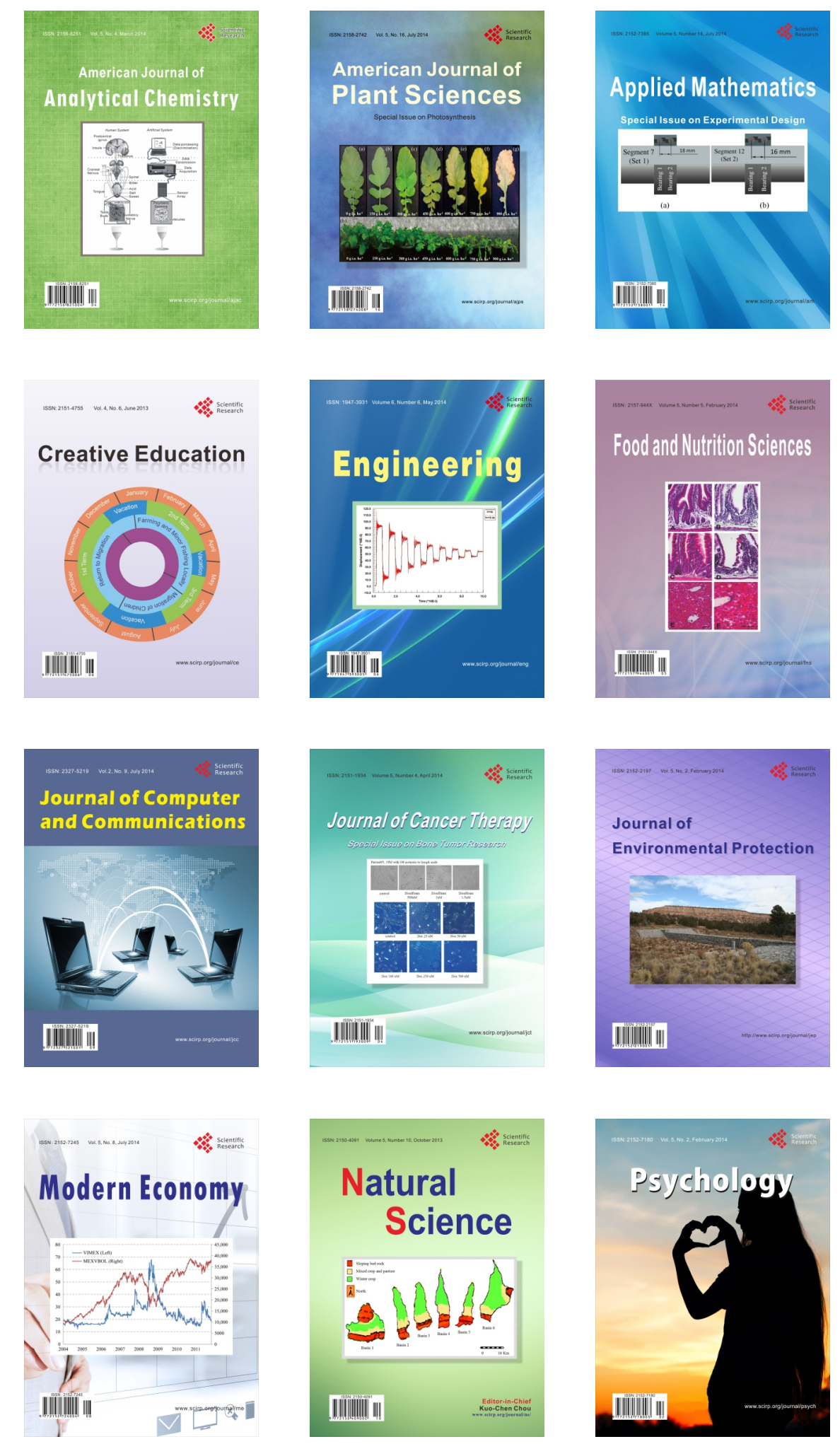